УДК 656.224.027

\title{
ІННОВАЦЙНИЙ РОЗВИТОК ЗАЛІЗНИЧНОГО ТРАНСПОРТУ В УКРАЇНІ ШЛЯХОМ СТАНОВЛЕННЯ ШВИДКІСНОГО РУХУ
}

\author{
Назаренко І.Л., к.е.н., доцент, \\ Шевченко П.М., слухач магістратури ТЕМПУС (УкрДУЗТ)
}

В статті на основі аналізу належності швидкісного руху до певних типів інновацій з'ясовано, щуо його можна віднести до товарних (послугових) інновачій. Крім того, впровадження швидкісного руху тягне за собою інноваџії як безпосередньо виробничі, так $і$ організачійно-управлінські. Проаналізовано обсяги перевезень пасажирів та населеність поїза Інтерсіті та Інтерсіті + , зроблений висновок про зростання попиту на швидкісні перевезення в Украӥні.

Систематизовані основні фактори, які впливають на впровадження швидкісного руху в Украӥні, вони розділені на групи за їх природою (технічні, фінансово-економічні, сочіальні, політичні, екологічні) та по відношенню до ПАТ «Украӥнська залізниия» (ендогенні та екзогенні).

Ключові слова: інноваційний розвиток, залізничний транспорт, швидкісний рух, фактори розвитку швидкісного руху

\section{ИННОВАЦИОННОЕ РАЗВИТИЕ ЖЕЛЕЗНОДОРОЖНОГО ТРАНСПОРТА В УКРАИНЕ ПУТЕМ СТАНОВЛЕНИЯ СКОРОСТНОГО ДВИЖЕНИЯ}

\author{
Назаренко И.Л., к.э.н., доцент; \\ Шевченко П.М., слушатель магистратуры ТЕМПУС (УкрГУЖТ)
}

В статье на основе анализа принадлежности скоростного движения $\kappa$ определенным типам инноваций выяснено, что его можно отнести $к$ товарным инновациям (инновациям услуг). Кроме того, внедрение скоростного движения влечет за собой инновачии как непосредственно производственные, так и организачионноуправленческие. Проанализировань объемы перевозок пассажиров и населенность поезда Интерсити и Интерсити +, сделан вывод о росте спроса на скоростные перевозки в Украине.

Систематизированы основные факторы, влияющие на внедрение скоростного движения в Украине, они разделень на группь по их природе (технические, финансовоэкономические, сочиальные, политические, экологические) и по отночению к ОАО «Украинская железная дорога» (эндогенные и экзогенные).

Ключевые слова: инновационное развитие, жселезнодорожный транспорт, скоростное движение, факторы развития скоростного движения 


\title{
INNOVATIVE DEVELOPMENT OF RAILWAY TRANSPORT IN UKRAINE THROUGH THE FORMATION OF HIGH-SPEED TRAFFIC
}

\author{
Nazarenko I.L., PhD (economics), assistant professor, \\ Shevchenko P.M., student of master's TEMPUS programme (USURT)
}

Railway transport is one of basic industries, providing transportation of goods and passengers, and is known to be a basis of national economy of Ukraine.

One of the most important directions of innovative development of railway transport in Ukraine is the introduction and advancement of high-speed traffic.

According to classification of the main types of railway transport innovations, high-speed traffic can be attributed to commodity (service) innovations, namely - to innovations in raising the level and quality of transport services, because passengers are provided with an improved service - transportation at high speeds and with greater comfort.

In 2012 the Ukrainian Railways Express Company was created - the first Ukrainian company for passenger transportation by day high-speed trains INTERSITI +.

In the article we analyzed the volumes of passenger transportation by high-speed trains in Ukraine in 2012 - 2016 and the average population of trains in different directions. Thus, we see that high-speed rail passenger traffic in Ukraine increases every year. Let's note that the current prospects for their development are given by the huge tourist and recreational potential of Ukraine, demand for travelling to the EU countries, the development of rail tourism. But the further development of high-speed traffic depends on many factors.

The main key factors that influence the introduction of high-speed traffic in Ukraine are systematized in the article, they are divided into groups according to their nature (technical, financial, economic, social, political, environmental) and according to relation to PJSC "Ukrainian Railways" (endogenous and exogenous). For instance, the most important endogenous technical factors are: the state of railway tracks and the infrastructure as a whole; level of electrification of railway lines; condition of locomotive and car park.

The most important endogenous social factors are: HR policy of PJSC "UZ" in the field of providing high-speed traffic; availability of the necessary human resources for introduction of high-speed traffic; the level of labor productivity, etc. Exogenous social factors are: effective demand for high-speed transportation; level of development of rail tourism (and demand for it); desire of people to reduce time for a trip, etc.

Key words: innovative development, railway transport, high-speed traffic, factors of development of high-speed traffic

Постановка проблеми. Залізничний транспорт України є провідною галуззю в дорожньо-транспортному комплексі країни, який забезпечує майже $82 \%$ вантажних і 36\% пасажирських перевезень, здійснюваних всіма видами транспорту.

Необхідно зазначити, що, згідно 3 Законом про пріоритетні напрями інноваційної діяльності в Україні від 8 вересня 2011 року N 3715-VI (стаття 4), до стратегічних пріоритетних напрямків на 2011 - 2021 роки відноситься «освоєння нових технологій високотехнологічного розвитку транспортної системи», що обумовлює актуальність та своєчасність досліджень в галузі інноваційного розвитку залізничного транспорту.

Інноваційний розвиток залізничного транспорту - це цілеспрямований систематичний процес позитивних змін якісного стану всіх його підсистем (виробничої, маркетингової, фінансової, управлінської та ін.) через впровадження інновацій (розроблених як власними, так i зовнішніми силами) в діяльність залізничного транспорту 3 метою досягнення як цілей 
інноваційної діяльності, так і стратегічних цілей ПАТ «Українська залізниця».

Як відмічено у Національній транспортній стратегії України на період до 2030 року, на сьогодні транспортна галузь в цілому задовольняє лише основні потреби населення та економіки в перевезеннях за обсягом, але не за якістю. Сучасний стан транспортної галузі не повною мірою відповідає вимогам ефективної реалізації евроінтеграційного курсу України та інтеграції національної транспортної мережі в Транс'європейську транспортну мережу.

Серед переліку загальних проблем, що потребують розв'язання, у Національній транспортній стратегії відмічено технологічне відставання транспорту та інфраструктури, низький рівень впровадження сучасних технологій та реалізації інноваційної політики в транспортну галузь. А у переліку завдань, які необхідно виконати для розв'язання проблем, вказано забезпечення комплексного інноваційного розвитку транспорту, зокрема шляхом реалізації державної стратегії (цільового підходу) інноваційної діяльності i розвитку та інвестиційних проектів у транспортній галузі, зокрема високошвидкісного залізничного руху.

Зважаючи на тенденції розвитку швидкісного та високошвидкісного руху на залізницях Європи та світу та курс українських залізниць на інтеграцію в європейську транспорту систему, вельми актуальним $є$ дослідження становлення швидкісного руху в Україні та шляхів підвищення його ефективності як напрямку інноваційного розвитку залізничного транспорту.

\section{Аналіз останніх досліджень $i$} публікацій. Проблемам інноваційного розвитку залізничного транспорту присвячена велика кількість наукових праць. Значний внесок належить таким вченим, як Є.М. Сич та В.П. Ільчук, які розробили концепцію інноваційно-інвестиційного розвитку залізничного транспорту [1], В.Л. Дикань та В.О. Зубенко, монографія яких [2] присвячена забезпеченню ефективності інноваційної діяльності підприємств залізничного транспорту; В.Л. Дикань, О.Г. Кірдіна, І.Л. Назаренко, Ю.М. Уткіна, робота яких [3] присвячена питанням економіки та організації інноваційної діяльності на залізничному транспорті, О.Г. Кірдіна, у працях якої розроблені концептуальні основи інвестиційно-інноваційного розвитку залізничного комплексу [4 та ін.]; М.В. Корінь, яка запропонувала економічний механізм забезпечення інноваційного розвитку залізничного транспорту [5] та ін. Проблемами становлення швидкісного руху в останні роки займалися А. А. Босов, Ю. С. Бараш, О.М. Гненний, А.В. Момот, Т. Ю. Чаркіна, В. Л. Дикань, Ю. В. Слагін, Ю. Ф. Кулаєв. Є. М. Сич, І. М. Аксьонов. В. П. Гудкова О. М. Гудков, Зайцева І.Ю., О. О. Карась, М.О. Срьоміна [6 - 10] та інші учені, в працях яких розроблено основи впровадження швидкісного руху в діяльність українських залізниць.

Виділення недосліджених аспектів проблеми. Але дотепер недостатньо розробленими $є$ питання організації швидкісних перевезень як шляху інноваційного розвитку залізничного транспорту України в умовах іiі євроінтеграції, потребують подальшого дослідження фактори впровадження швидкісного руху в Україні.

Метою статmі є дослідження шляхів інноваційного розвитку залізничного транспорту саме через подальше становлення швидкісного руху, виявлення та систематизація факторів розвитку швидкісного руху в Україні.

Основний матеріал статmі. Згідно світової практики, виділяють два способи вирішення проблеми підвищення швидкості:

- організація швидкісного руху на існуючих лініях (160 - 200 км/год.);

-будівництво та введення в експлуатацію спеціалізованих високошвидкісних магістралей (для досягнення швидкостей більше 200 км/год.). 
Другий спосіб потребує величезних інвестицій, а перший можна реалізовувати шляхом модернізації існуючих ліній. Тому учені (зокрема, у [11]), визнають, що поки що високошвидкісні магістралі в Україні $\epsilon$ неефективним проектом, i необхідно розширювати мережу швидкісного руху.

Концепція впровадження швидкісного руху пасажирських поїздів на залізницях України в $2004-2015$ рр. була прийнята ще у 2004 році, і 3 тих пір велися роботи по підготовці впровадження швидкісного руху.

Згідно 3 класифікацією основних напрямів інновацій на залізничному транспорті Є.М Сича та В.П. Ільчука [1], швидкісний рух можна віднести до товарних (послугових) інновацій, а саме до інновацій з підвищення рівня та якості транспортних послуг, 3 огляду на те, що пасажирам надається удосконалена послуга - перевезення підвищеною швидкістю та з більшим рівнем комфорту. 3 іншого боку, організація швидкісного руху тягне за собою впровадження інновацій безпосередньо виробничих (інновацій процесу виробництва транспортних послуг), а саме - технічних (інновацій в основні фонди, передовсім новий рухомий склад), а також технологічних (інновації в технологічний процес перевезень), зокрема організація нових форм та методів комплексного та фірмового обслуговування. Крім того, впровадження швидкісного руху вимагає й організаційно-управлінських інновацій (зокрема, реструктуризації управлінського апарату, впровадження нових методів управління).

Такі інновації були здійснені у 2012 році, коли була створена Українська залізнична швидкісна компанія - перша в Україні компанія з перевезення пасажирів денними швидкісними поїздами IHTEPCITI+. Філія «Українська залізнична швидкісна компанія» ПАТ «Українська залізниця» $\epsilon$ відокремленим підроздом публічного акціонерного товариства «Українська залізниця» і не має статусу юридичної особи; створена 3 метою розширення та покращення комплексу послуг, що надаються пасажирам під час поїздки у швидкісних поїздах.

Сьогодні на балансі Української залізничної швидкісної компанії обліковується рухомий склад: 10 швидкісних міжрегіональних електропоїздів подвійного живлення моделі HRCS2 виробництва компанії «Hyundai Rotem» (Корея); 2 швидкісних міжрегіональних електропоїзда подвійного живлення моделі ЕКр-1 вітчизняного виробництва ПАТ «Крюківський вагонобудівний завод»; 2 швидкісних двоповерхових електропоїзда подвійного живлення моделі ЕЈ 675 виробництва компанії «Skoda Vagonka» (Чеська Республіка); 10 пасажирських вагонів поліпшеної конструкції, 3 експлуатаційною швидкістю 160 км/год вітчизняного виробництва ПАТ «Крюківський вагонобудівний завод», які експлуатуються у складі двох міжрегіональних поїздів у п'ятивагонній комплектації [12].

Основними перевагами послуг, які надаються пасажирам швидкісних поїздів Української залізничної швидкісної компанії, $\epsilon$ :

- час подорожі (час подорожі денними швидкісними поїздами IHTEPCITI+ $\epsilon$ співрозмірним iз аналогічним та не набагато більшим, ніж під час подорожі літаком;

- вартість перевезень (прямими конкурентами за вартістю перевезень $\epsilon$ організації, які надають аналогічні за функціональним призначенням послуги, це авто- та авіатранспорт);

- надійність (залізничний транспорт - найбезпечніший транспорт у світі. Запорукою надійності швидкісних поїздів IHTEPCITI+ $\epsilon$ ще i комплекс систем безпеки руху нового покоління);

- комфорт (подорожі швидкісними поїздами IHTЕРСІТІ+ $\epsilon$ комфортними та зручними для пасажирів за рахунок сучасного рухомого складу із затишним інтер'єром, який 
створено 3 урахуванням всіх законів ергономіки);

- зручний розклад руху (розклад руху розроблено 3 урахуванням максимального попиту пасажирів 3 відправленням поїздів вранці та ввечері, що дозволяє пасажирам більш оптимально спланувати свій день і здійснити поїздку туди/зворотно протягом доби);

- сервіс (Українська залізнична швидкісна компанія вперше в Україні запровадила концептуально новий підхід в обслуговуванні пасажирів під час перевезень залізничним транспортом, який полягає в наданні комплексу матеріальних і нематеріальних послуг для забезпечення комфортної, швидкої та приємної подорожі).

Основними напрямками розвитку та стратегією Української залізничної швидкісної компанії $\epsilon$ поліпшення умов проїзду пасажирів за рахунок комфортабельних поїздів i висококваліфікованого персоналу.

Впровадження в Україні високої швидкості руху викликає необхідність вирішення нових досить складних проблем: підвищення технічного рівня інфраструктури залізниць; виробництво швидкісного рухомого складу та різної залізничної техніки; створення нових автоматизованих систем інформаційних технологій. Як свідчить досвід залізниць іноземних держав, на лініях із суміщеним рухом вантажних і пасажирських поїздів швидкість руху пасажирських поїздів через значні відмінності технічних параметрів для різних видів руху має обмеження. Вона, як правило не перевищує 200-220 км/год.

Розглянемо динаміку перевезення пасажирів швидкісними поїздами в Україні (див. рис. 1).

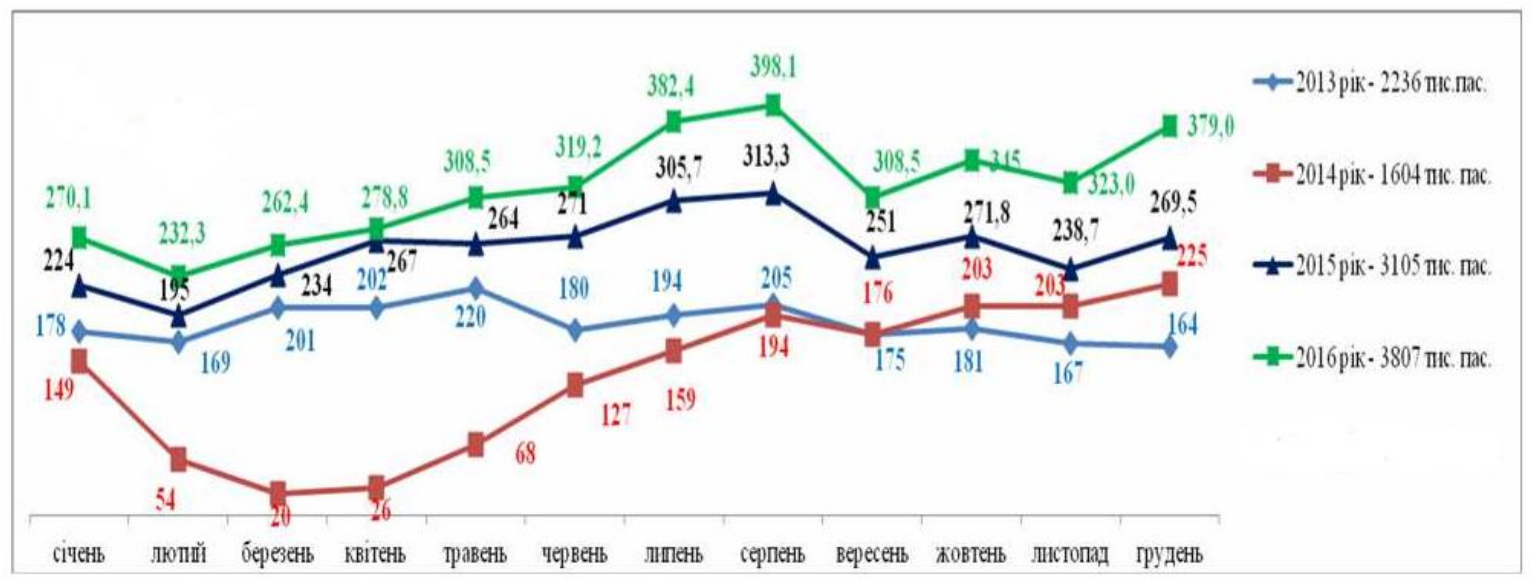

Рис. 1. Перевезення пасажирів швидкісними поїздами категорії Інтерсіті+ та Інтерсіті по місяиях року, тис. пас.

Як бачимо, протягом чотирьох років наявні тенденція до збільшення кількості пасажирів, тобто, швидкісні поїзди стають все більш популярними. Пік перевезень традиційно припадає на літні місяці липень і серпень, період відпусток.

З 2013 року по 2016 рік середня населеність поїздів класу «Інтерсіті+» в
Україні збільшилась $3 \quad 49$ до $64 \%$ відповідно. При цьому населеність вечірнього рейсу Київ - Харків у другому кварталі 2016 р. досягла неймовірного показника в $91 \%$. Середня населеність поїздів «Інтерсіті +» за I та II півріччя 2015 р. у відсотках подана на рис. 2. 


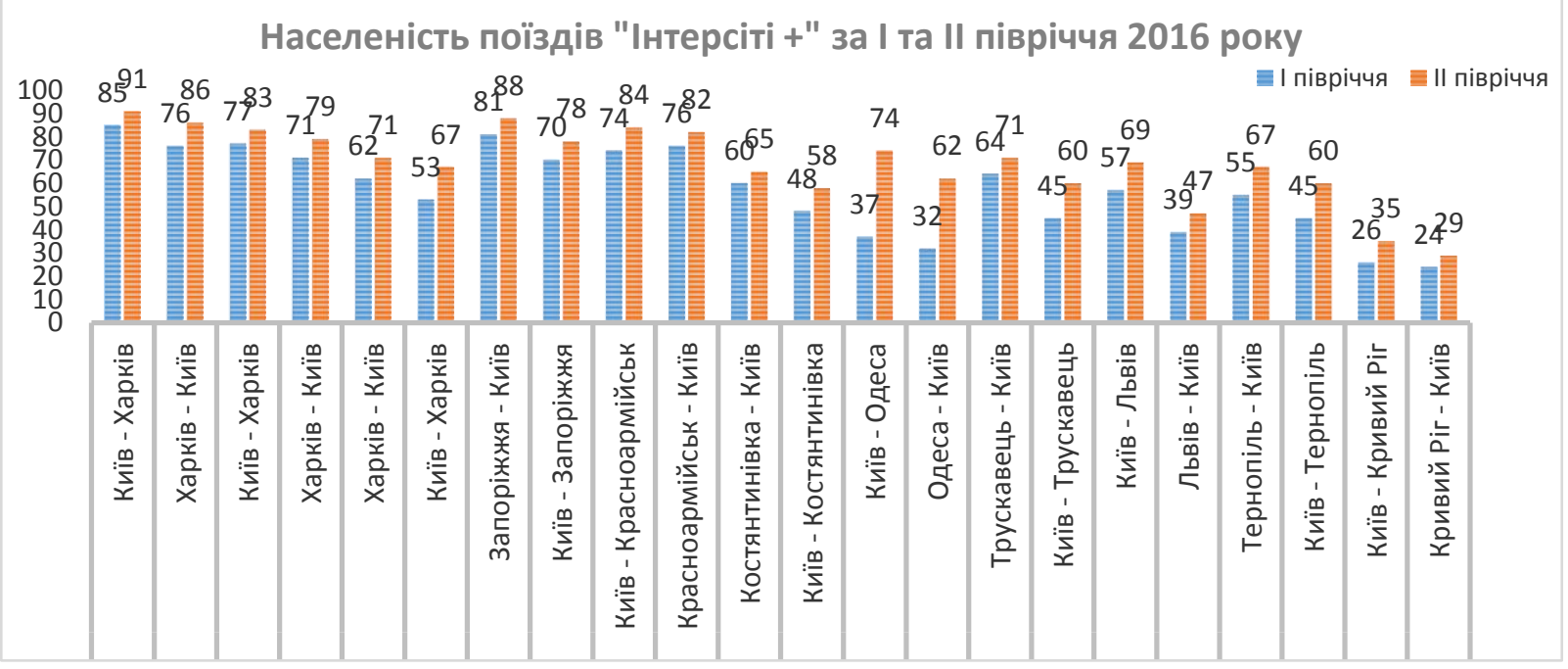

Рис. 2. Населеність поїда Інтерсіті+ за I та II півріччя 2016 р.

Порівнюючи залізничне пасажирське швидкісне сполучення 3 європейськими країнами, бачимо, що середнє завантаження наших поїздів класу «Інтерсіті+» задовільне.

Наприклад, у Польщі середня завантаженість поїздів «Репбоіпо» дуже неоднорідна. Так, на найпопулярнішому напрямку Варшава - Краків - Варшава завантаження є на рівні 79-85 \%, на всіх інших - менше 37 \%. Варшава - Катовіце - взагалі 25 \%. Завантаження поїздів «СеБке бгау» (державний пасажирський залізничний оператор Чехіï) у 2014 році склало $26 \%$.

Таким чином, бачимо, що швидкісні залізничні пасажирські перевезення в Україні зростають 3 кожним роком. Відмітимо, що наявні перспективи їх розвитку, 3 огляду на величезний туристично-рекреаційний потенціал України, потенційний попит на поїздки до країн $€$, розвиток залізничного туризму.

Але подальший розвиток швидкісного руху залежить від багатьох факторів. Ми зробили спробу систематизувати основні фактори, які впливають на впровадження швидкісного руху в Україні, розділивши їх на групи за їх природою та по відношенню до ПАТ «Українська залізниця» (див. рис. 3).

Висновки і перспективи подальщих досліджень. Отже, в статті на основі аналізу належності швидкісного руху до певних типів інновацій з'ясовано, що його можна віднести до товарних (послугових) інновацій, а саме - до інновацій 3 підвищення рівня та якості транспортних послуг. Крім того, впровадження швидкісного руху тягне за собою інновації як безпосередньо виробничі, так i організаційно-управлінські.

В статті зроблений висновок про зростання попиту на швидкісні перевезення в Україні. Систематизовані основні фактори, які впливають на впровадження швидкісного руху в Україні, вони розділені на групи за їх природою (технічні, фінансово-економічні, соціальні, політичні, екологічні) та по відношенню до ПАТ «Українська залізниця» (ендогенні та екзогенні).

Напрямками подальших досліджень може стати обгрунтування впровадження нових маршрутів швидкісних поїздів в межах Україні та країн ЄС. 


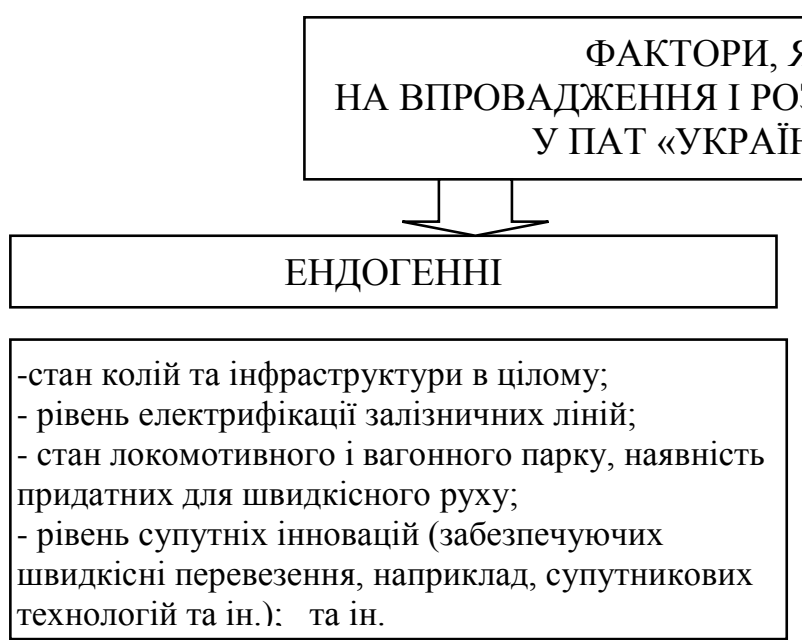

-економічна ефективність впровадження швидкісного руху;

-наявність фінансових коштів для модернізації інфраструктури і закупівлі рухомого складу;

- швидкість окупності інвестицій в інноваційні проекти на залізничному транспорті;

- прагнення до підвищення конкурентоспроможності залізничного транспорту та ін.

-кадрова політика ПАТ «УЗ» в області

забезпечення швидкісного руху;

- наявність необхідного кадрового потенціалу для

впровадження швидкісного руху;

- рівень продуктивності праці на залізничному

транспорті (надто низький) та ін.

-прагнення до інтеграції залізничного

транспорту до Європейської транспортної

системи;

- потреба у підвищенні якості послуг;

- організація швидкісних поїздів до країн СС

- прагнення мінімізувати шкідливий вплив

залізничного транспорту на навколишне

середовище
TEX-

HIYHI

ФIHAH-

COBO-

EKOHO-

MIYHI

СОЦІ-

АЛЬНІ

ПОЛІ

ТИЧнІ

ЕКОЛО-

ГІЧНІ
ЕКЗОГЕННІ

-рівень техніки і технологій в

Україні;

- рівень техніки і технологій в країнах - виробниках рухомого складу (який експортується для швидкісних перевезень та ін.

\begin{tabular}{|l|} 
- зацікавленість керівництва \\
України та областей у впровадь- \\
женні швидкісного руху, який \\
стимулюватиме їх економічне \\
зростання; \\
- наявність партнерів-інвесторів, \\
зацікавлених у фінансуванні \\
інноваційних проектів ПАТ «УЗ»
\end{tabular}

\begin{tabular}{|l|}
\hline - платоспроможний попит на- \\
селення на швидкісні перевезення; \\
- $\quad$ рівень розвитку залізничного \\
туризму (і попиту на нього); \\
$-\quad$ бажання людей скоротити час \\
на поїздку $\quad$ та ін..
\end{tabular}

- рівень політичної стабільності;

- рівень державної підтримки

інноваційних проектів ПАТ «УЗ»;

- євроінтеграційні наміри України;

- прагнення до підвищення

міжнародної конкурентоспроможності

як в Україні, так і країнах СС,

залізничний транспорт є найбільш екологічним і повинен розвиватися

Рис. 3 Фактори впровадження швидкісного залізничного руху.

ПЕРЕЛІК ВИКОРИСТАНИХ ДЖЕРЕЛ

1. Сич С.М, В.П. Ільчук. Інноваційноінвестиційний розвиток залізничного транспорту. - К.: Логос, 2002. - 256 с.

2. Дикань В.Л., Зубенко В.О. Забезпечення ефективності інноваційної діяльності підприємств залізничного транспорту: Монографія. - Х.: УкрДАЗТ, 2008. - 194 c.

3 Економіка і організація інноваційної діяльності на залізничному транспорті: Навчальний посібник. / В.Л. Дикань, О.Г. Кірдіна, І.Л. Назаренко, Ю.М. Уткіна / Під ред. В.Л. Диканя. - Харків: УкрДАЗТ, 2014. - 225 с. 4 Кірдіна О.Г. Методологічні аспекти інвестиційно-інноваційного 
залізничного комплексу України: монографія.

- Харків: УкрДАЗТ, 2011. - 312 с.

5 Корінь М.В. Економічний механізм забезпечення інноваційного розвитку залізничного транспорту // Зб. наук. пр. Держ. екон.-технол. ун-ту транспорту. Сер. Економіка і управління. - К., 2012. - Вип. 20. C. 112-117.

6 Бараш Ю.С., Гненний О.М., Момот А.В. Аналіз роботи швидкісного руху в Україні // Залізничний транспорт. -2014. -С. 53-62.

7 Босов А. А., Кирпа Г. Н. Формирование вариантов рациональной сети линий высокоскоростного движения поездов в Украине - Дніпропетровськ.: Дніпропетр. нац. ун-т залізн. трансп. ім. акад. В. Лазаряна, 2004. $-144 \mathrm{c}$.

8 Дикань, В.Л., Корнилова И.В. Скоростное движение железнодорожного транспорта в мире и перспективы его развития в Украине // Вісник економіки транспорту та промисловості. - 2010. - № 32. - С. 15-25.

9 Зайцева І.Ю. Особливості створення на залізницях України мережі швидкісних залізничних магістралей // Вісник економіки транспорту і промисловості № 60, 2017. - С. 86 $-93$.

10 Єрьоміна М.O. Забезпечення конкурентоспроможності залізничних пасажирських перевезень за рахунок швидкісного руху: Автореферат .. канд.. екон. наук.. - Харків, УкрДУЗТ, 2009. - 22 с.

11 . Овчиннікова В.О., Габєлков М.В. Стратегічне управління високошвидкісними залізничними перевезеннями // Вісник економіки транспорту і промисловості. - № 59, 2017. - c. $76-84$.

12 Філія «Українська залізнична швидкісна компанія» // https://www.uz.gov.ua/about/general_informatio n/entertainments/ukrainian_fastspeed_railway_c ompany/

\title{
ІНВЕСТИЦЙНЕ ЗАБЕЗПЕЧЕННЯ РОЗВИТКУ ПІДПРИЕМСТВ ЖИТЛОВО-КОМУНАЛЬНОГО ГОСПОДАРСТВА
}

\author{
Чорнобровка I.В., к.е.н., доцент, \\ Зорянська В.А., магістр, \\ Шаріков С.С., махістр (УкрДУЗТ)
}

У статті авторами досліджено сучасні тенденції функиіонування підприємств житлово-комунального господарства. Визначено, щчо наразі житлово-комунальні підприємства знаходяться в досить скрутному фінансово-економічному становищі, яке характеризується високим рівнем їх збитковості. Проаналізовано динаміку видатків державного та місиевого бюджетів на утримання житлово-комунального господарства, щуо дозволило визначити невідповідність планових та фактичних обсягів фінансування й поступового зменшення їх розміру. Розкрито сукупність факторів, що зумовлюють виникнення кризового стану підприємств жстлово-комунального господарства. Серед основних причин виникнення такого становища виділяють зменшення обсягів бюджетного фінансування галузі, невідповідність тарифів на житлово-комунальні послуги та рівня фактичних витрат, накопичення дебіторської заборгованості підприємствами житлово-комунального господарства унаслідок

(C) Чорнобровка I.В., Зорянська В.А., Вісник економіки транспорту і промисловості № 64, 2018 Шаріков С.С. 